\title{
Effect of the liming on the soil chemical properties and the development of tomato crop in Sucre- Colombia
}

\begin{abstract}
The acidity of the soil produces complex interactions on plant growth limiting factors that involve physical, chemical and biological properties of the soil, which can manifest in deficiencies of calcium, magnesium and phosphorus and toxicity of aluminum, iron, and manganese, which could limit plant growth. Based on the above and in order to contribute to better development of tomato crop in soils with a low nutritional offer and acid reaction of the Santa Clara region (Sucre), the following research has been proposed with five (5) commercial lime dose $\left(0,1,2,3\right.$ and $\left.4 \mathrm{tha}^{-1}\right)$ and its effect on chemical properties, using tomato as an indicator plant. The effect on $\mathrm{pH}, \mathrm{P}, \mathrm{Ca}, \mathrm{Mg}$ and $\mathrm{K}$ in the soil was evaluated, and in the plant, the yield components were evaluated (weight and dimensions of the fruit, yield). A completely randomized design with three repetitions was used, the information was processed with the statistical software SAS version 9.1. It was found that liming improves soil $\mathrm{pH}$, availability of $\mathrm{P}, \mathrm{Ca}, \mathrm{Mg}$ and $\mathrm{K}$, in the same way, the development and yield of tomato crop with doses of up to $3 \mathrm{tha}^{-1}$ of lime on the soil is improved.
\end{abstract}

Volume 7 Issue 2 - 2020

\author{
Eliecer Miguel Cabrales Herrera, Luis \\ Fernando Acosta Pérez \\ Sustainable Agriculture Research Group, Universidad de \\ Córdoba, Colombia
}

\begin{abstract}
Correspondence: Eliecer Miguel Cabrales Herrera Universidad de Córdoba, Sustainable Agriculture Research Group, Universidad de Córdoba, Montería, Colombia,
\end{abstract} Email ecabralesh@correo.unicordoba.edu.co

Received: April 07, 2020| Published: April 30, 2020

Keywords: liming in sucre, exchangeable acidity, tomato yield, tomato production, exchangeable aluminum

Abbreviations: $\mathrm{CRD}$, completely randomized design; $\mathrm{Ca}$, calcium, Mg, magnesium

\section{Introduction}

The acidity of the soil with the low availability of nutrients, are one of the greatest limitations that can induce the low productivity of acid soils. Although acidification is a natural process, agriculture, pollution, and other human activities accelerate this process, ${ }^{1}$ becoming one of the most common limitations in Colombian soils, where aluminum and iron can in conditions of excess, be toxic to crops, or its in effect retain phosphorus. The chemical interactions derived from acidity affect the fertility of the soil, by altering its ionic balance and inhibiting the absorption of important nutrients, such as calcium, magnesium, and phosphorus..$^{2-4}$ It is estimated that $40 \%$ of the world's cultivable soils are acidic and potentially have toxic effects of aluminum, iron, and manganese, which usually happens when the $\mathrm{pH}$ is below 5.5. Under these conditions, aluminum appears in the soil solution as $\mathrm{Al}^{3+}$, which is a free ion that can form compounds with other ions present in the solution such as phosphates and sulfates. These $\mathrm{Al}^{3+}$ ions can also compete with other cations such as $\mathrm{Ca}^{2+}$ and $\mathrm{Mg}^{2+}$ for exchange sites in soil colloids, contributing to the washing of these interchangeable bases, so that the exchangeable aluminum potentially becomes a limiting factor in the fertility of the majority of acid soils. ${ }^{5,6}$ The effects of acidity directly affect the fertility of the soils and are the determining factors in the evaluation of agricultural productivity, hence the importance of its valuation in establishing management strategies. ${ }^{6,7}$ To reduce the acidity of the soil, fine limestone rock material ( $<0.25$ microns $)$ is used, ${ }^{8}$ which in its reaction releases $\mathrm{OH}^{-}$groups that react with aluminum and hydrogen in the soil solution and neutralizes them, lowering their concentration and thereby increasing the $\mathrm{pH}$ of the soil. Likewise, the calcium provided in management plans (liming or fertilization) can displace these elements from the exchange sites, thereby releasing retained nutrients in the colloidal system the soils. ${ }^{9}$

The $\mathrm{pH}$ or reaction of the soil limits the implementation of many cultivars, not only because of the high concentration of $\mathrm{H}^{+}$(low $\mathrm{pH}$ ), but they tend to be low in exchangeable bases, including calcium that contributes to the hardness of the cell wall, the magnesium that is part of the chlorophyll molecule, the potassium that is indispensable for turgor of fruits and the plant in general. In this order of ideas, crops that tolerate these conditions should be selected, which must be supplied in the fertilization plans, the missing nutrients for good development and yield.The soils of the El Roble municipality of the department of Sucre, are of acid reaction and low nutritional offer, the community in small areas sows vegetables including tomato for fresh and local consumption, in which multiple plant health problems appear as the apical rot of the fruit, leaf fungus and stem, possibly leading to low crop yields. In this sense, the tomato is a plant that demands high amounts of nutrients and the production of fruits of good caliber and high weight is related to the availability of nutrients in each of the stages of crop growth. ${ }^{6}$ Some studies have shown that the application of calcium amendments to the soil, raise the $\mathrm{pH}$ and increase the yield of tomato fruits, ${ }^{10,11}$ has been shown the positive effect of calcium available in the soil on the yield of the tomato crop, induces a positive effect on the appearance and weight of the fruit. ${ }^{12}$ Based on the above and in order to contribute to the productivity of the agricultural area of Community of El Roble - Sucre, this research was proposed with the objective of evaluating the effect of the application of different doses of agricultural lime on the chemical properties of a soil acid and its effect on tomato crop yield under semi-controlled conditions.

\section{Materials and methods}

The investigation was conducted in semi-controlled conditions in the El Roble - Sucre community, geographically located $9^{\circ} 6$ 'north 
latitude and $75^{\circ} 11^{\prime}$ west longitude of the Greenwich Meridian, conformed by lomerío and undulations that go from 70 to 185 m.s.n.m. The climate is characteristic of tropical dry forest areas. The average annual temperature is $27.2^{\circ} \mathrm{C}$, the precipitation fluctuates between 990 and $1,275 \mathrm{~mm}$ annual average and the relative humidity is $80 \%$ on average. The physiographic, edaphic factors, winds, and degenerative anthropic actions of the natural environment, eliminate tree cover and degrade the soil, produce acidity conditions in the soil.The 20 $\mathrm{cm}$ deep soil of the Las Lauras estate of the Santa Clara district was used, municipality El Roble of the department of Sucre, the soil of frank sandy texture, considered as extremely acidic (Table 1), organic matter content low and nutritional offer low.

Table I Physicochemical characteristics of the soil used in the trial

\begin{tabular}{ccccccccccc}
\hline $\mathbf{p H}$ & $\mathbf{M O}$ & $\mathbf{P}$ & $\mathbf{C a}$ & $\mathbf{M g}$ & $\mathbf{N a}$ & $\mathbf{K}$ & $\mathbf{A l}$ & $\% \mathbf{A}$ & $\% \mathbf{L}$ & Loamy sand \\
\hline- & $\%$ & $\mathrm{mg} / \mathrm{kg}$ & $\mathrm{cmol}+\mathrm{kg}$ & & & & & & & \\
4,3 & 0,3 & 5,9 & $\mathrm{I}, 2$ & 0,8 & 0,4 & 0,01 & 8,9 & 82,5 & 14,3 & 3,2 \\
\hline
\end{tabular}

Doses of $0,1,2,3$ and $4 \mathrm{t} \mathrm{ha}^{-1}$ of commercial agricultural lime available in the area, whose composition is $37.05 \% \mathrm{CaO}$ and $5.35 \% \mathrm{MgO}$, were applied to the soil, it was spread on the surface and incorporated in the first $5 \mathrm{~cm}$ of depth, then, water was added until it was completely moistened, left for 40 days in incubation with field moisture, during which time, $95 \%$ of the lime had reacted (Lime Residuality Index 5\%).Seedbed was made in soil substrate: compost in a 2:1 ratio, it was solarized for 3 days in $10 \mathrm{~cm}$ layers, covered by plastic. When the seedlings had 3 true leaves (20 days), a transplant was made to nursery bags with a capacity of $20 \mathrm{~kg}$, previously filled with soil from the Las Lauras farm. These bags were located at a distance of $0.8 \mathrm{~m}$ by $0.6 \mathrm{~m}$.Fertilization was defined based on soil analysis and liming with the formula suggested by. ${ }^{13}$ The fertilization was done with $120 \mathrm{~kg} \mathrm{ha}^{-1}$ of nitrogen (Urea source, $46 \%$ of N), applied in a fractional form in three doses at 15,30 and 45 days after transplantation. The phosphorus dose was $80 \mathrm{~kg} \mathrm{ha}^{-1}$ (DAP source, 18-46-0), applied in two fractions the first in pre-planting and the second 30 days after transplantation. The dose of potassium was $80 \mathrm{~kg} \mathrm{ha}^{-1}$ (source $\mathrm{KCl}, 60 \% \mathrm{~K}_{2} \mathrm{O}$ ) and its application was done in two fractions: one at the time of planting and the second 30 days after transplantation. For the supply of minor elements, a complete foliar fertilizer was used, with applications at 15, 30 and 45 days after sowing, sprinkling a solution with a concentration of $1 \mathrm{ml} \mathrm{L}^{-1}$. Throughout the crop cycle, all the necessary work was carried out to maintain the crop. To observe the effect of the treatments (liming) on the soil, the $\mathrm{pH}$ was determined at the beginning and at the end of the experiment (soil: water ratio 1:1, Metrohm equipment), the content of P (Bray II) was also measured, $\mathrm{Ca}, \mathrm{Mg}, \mathrm{K}$ (Ammonium acetate, quantification by spectrophotometry) and $\mathrm{Al}+\mathrm{H}(\mathrm{KCl}$, titration). The crop (tomato) was evaluated for yield, whose harvest of the fruits was done daily in those who had physiological maturity (reddish color). The following variables were evaluated: harvested fruits, fruit weight, fruit dimensions, and yield.The trial was established in a completely randomized design (CRD), with five treatments and three repetitions. The information was tabulated in Excel and processed with the statistical software SAS version 9.1, analysis of variance and regression was made at $5 \%$ probability.

\section{Results and discussion}

\section{Soil parameters}

Acidity of the soil:The analysis of variance showed significant statistical differences between the treatments for the $\mathrm{pH}$ variable (Table 2). In terms of $\mathrm{pH}$, all treatments are statistically different, to the control. Regarding the graphic behavior of the data, it can be evidenced that there is a linear adjustment for its modeling, with high statistical significance $(\mathrm{p}<0.01)$, indicating that the $\mathrm{pH}$ depends on $95.8 \%$ of the applied lime doses to the ground (Figure 1).

Table 2 Mean squares and levels of significance of the chemical properties of liming soil

\begin{tabular}{|c|c|c|c|c|c|c|c|}
\hline S.V. & DF & $\mathrm{pH}$ & $\mathbf{P}$ & $\mathbf{C a}$ & Mg & $\mathbf{K}$ & $\mathbf{A l}+\mathbf{H}$ \\
\hline Treatments & 4 & $0,74 * *$ & $1254,44 * *$ & $1,23 * *$ & $0,12^{*}$ & $0,08 * *$ & $332,62 * *$ \\
\hline Error & 10 & $3,0 \mathrm{E}-03$ & 6,78 & 0,01 & 0,02 & $5,5 \mathrm{E}-04$ & 0,05 \\
\hline C.V. (\%) & & $\mathrm{I}, \mathrm{I}$ & 7,84 & $5, I$ & 14,13 & 9,66 & 6,37 \\
\hline $\mathrm{R}^{2}$ & & 0,99 & 0,99 & 0,98 & 0,70 & 0,98 & 0,99 \\
\hline
\end{tabular}

DF, degrees of freedom;P, phosphorus; Ca, calcium; Mg, magnesium; K,potassium;exchangeable acidity,

$(\mathrm{Al}+\mathrm{H})$; $^{*}$, significant; ${ }^{* *}$, highly significant; ns, not significant 


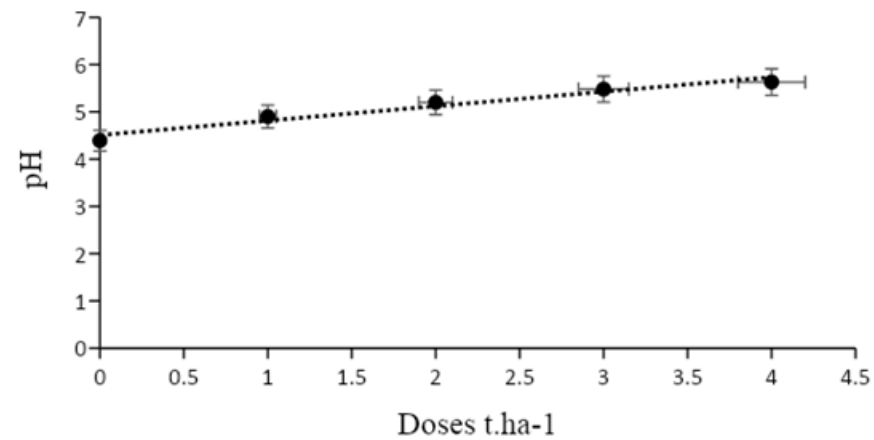

Figure I Effect of the doses of the calcium amendment on the $\mathrm{pH}$ of an acid soil.

The highest response to liming was observed with the application of the dose of $4 \mathrm{t} \mathrm{ha}^{-1}$ from an extremely acidic $\mathrm{pH}$ with a value of 4.3 to moderately acidic with a value of 5.63 . This is possibly due to the fact that the added lime reacted with the moisture available during the incubation period, and by reacting it releases $\mathrm{OH}^{-}$groups that react with the aluminum and hydrogen in the soil solution: it neutralizes them and increases the $\mathrm{pH}$, as it does affirms. ${ }^{9}$ The $\mathrm{pH}$ of the soil showed an ascending behavior with the increase in the dose of the of liming material, similar to those reported, ${ }^{2,3,6,14-17}$ who support the benefits obtained with the application of the liming material as a corrective for the acidity of the soil, and its effect on the chemical properties of the soil.

Exchangeable acidity: The dynamics of this variable conform to a linear order model (Figure 2) with high statistical significance (Table 2 ), explaining that the reduction in exchangeable acidity depends on $78.99 \%$ of the liming material. These results show that there are significant differences between treatments, the control treatment $(0 \mathrm{t}$ $\left.\mathrm{ha}^{-1}\right)$ is statistically different from the other treatments, demonstrating that the doses of the amendment eliminate a high percentage of exchangeable acidity.

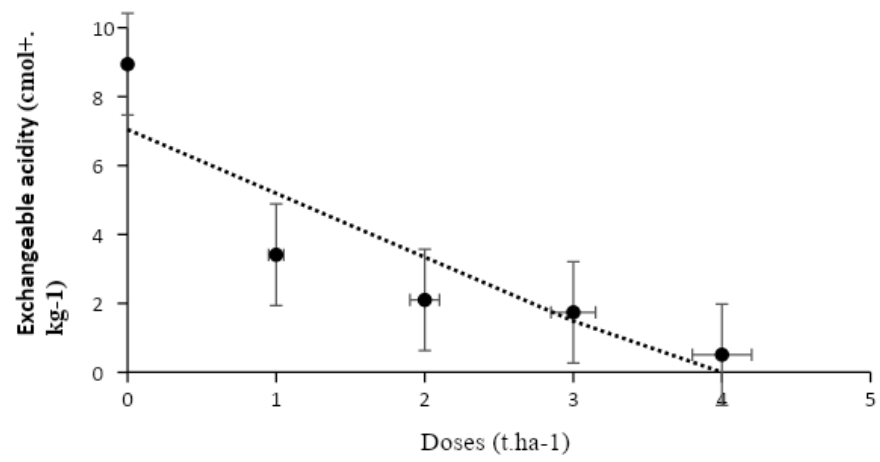

Figure 2 Effect of the doses of the calcium amendment on exchangeable acidity.

Contrary to what happens with $\mathrm{pH}$, the concentration of exchangeable acidity decreases as the dose of calcium amendment is increased. This behavior has been widely documented in soils, $2,14,15,18-20$ who state that when chemical corrective agents (limes) are applied to the soil, the exchangeable acidity decreases.

Phosphorus: The phosphorus content varies significantly (Table 2), all treatments are different from the control $\left(0 \mathrm{t} \mathrm{ha}^{-1}\right)$, there was a large increase in the phosphorus content in the soil, a trend that can be explained by a linear order model in $98.78 \%$ (Figure 3 ). The increase of the content of this element is possibly due to the contributions of the fertilizer (DAP) applied, the liberation of the element that is achieved by increasing the $\mathrm{pH}$ of the soil. This availability of the element was reflected in the good development of tomato cultivation. Similar results were obtained by other authors, ${ }^{3,6,21}$ who achieved better availability of the element with increases in soil $\mathrm{pH}$.

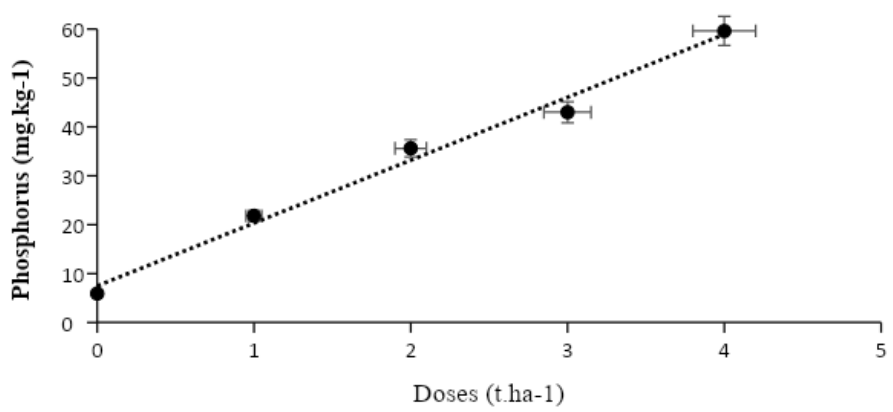

Figure 3 Effect of treatments on the phosphorus content in the soil.

Calcium, magnesium, and potassium: With liming, calcium and magnesium presented a highly significant increase (Table 2), which is consistent with that reported by other researchers, ${ }^{14,15}$ the same was presented for potassium but in smaller proportion. Similar results were obtained by Sikiric et al. ${ }^{22}$ with the application of lime in an inceptisol soil, thereby increasing the availability of $\mathrm{Ca}$ and $\mathrm{Mg}$ without significant changes in $\mathrm{K}$ levels. This can be explained because $\mathrm{Mg}$ (and $\mathrm{Ca}$ to a lesser extent) replaces $\mathrm{K}$ in the exchange complex ${ }^{23}$ and by being free or available in the soil solution, it can be washed with greater ease and at the end of the trial not be in large quantities. For $\mathrm{Ca}, \mathrm{Mg}$ and $\mathrm{K}$ the graphical behavior of the data, it can be evidenced that there is a linear adjustment for its modeling (Figure 4), with high statistical significance $(\mathrm{p}<0.01)$.

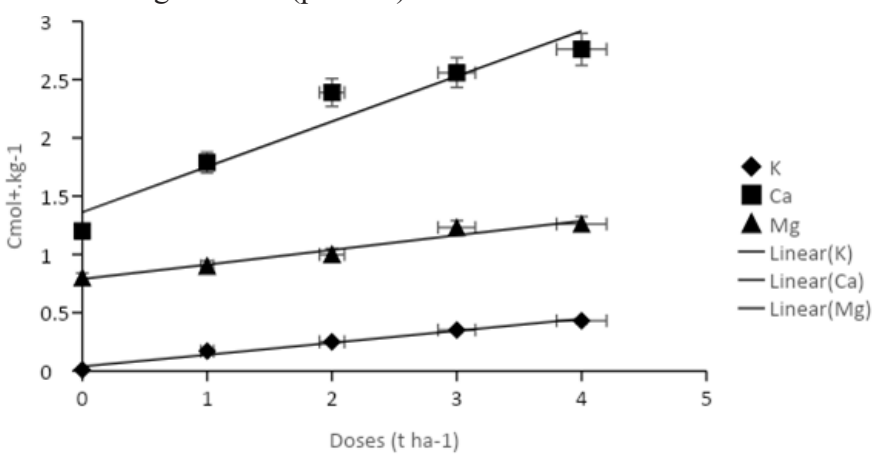

Figure 4 Effect of liming on the content of potassium, calcium and magnesium in the soil.

Comparing what happened in the soil without liming (T0), in the liming soil at the end of the experiment an increase in the levels of $\mathrm{P}, \mathrm{Ca}, \mathrm{Mg}$ and $\mathrm{K}$ available for the plant in the soil solution was observed, similar results reported. ${ }^{14}$ In this regard ${ }^{6,24}$ reported that depending on the liming sources used, their reaction mechanisms enrich the interchangeable phase with $\mathrm{Ca}^{++}$and $\mathrm{Mg}^{++}$once they produce aluminum displacement interchangeable in the soil solution so that an improvement in the concentration of bases is induced. On the other hand, as the $\mathrm{pH}$ becomes less acidic, phosphorus increases its availability or solubility. 


\section{Components of tomato crop yield}

Harvested fruits: As for the harvested fruits, the analysis of variance showed highly significant differences between treatments (Table 3 ). The fit of the model is good at a level of significance of $1 \%$, which suggests that $80.61 \%$ of the variability is explained by the model. Regarding the graphic behavior of the data, it can be evidenced that there is a quadratic adjustment for its modeling (Figure 5). In addition, an increase in the number of harvested fruits can be seen depending on the doses of lime up to the dose of $3 \mathrm{tha}^{-1}$, from this point the variable is dominated by a negative opening parabola that shows a decreasing trend.The increase in harvested fruits up to the $3 \mathrm{tha}^{-1}$ dose is probably due to the calcium assimilated by the plant joined with pectins, producing calcium pectate, which gives resistance to the cell wall against the attack of pathogens of fruit and thus the fruit does not lose firmness, ${ }^{12,25-28}$ so the probability of falling fruits is reduced.

Table 3 Mean squares and levels of significance of the components of tomato crop yield

\begin{tabular}{lllllll}
\hline S.V. & DF & NHF & FW & DF & FL & Yield \\
\hline Treatments & 4 & $176,27 * *$ & $129,73^{* *}$ & $11,94 * *$ & $16,54 *$ & $143,31 *$ \\
Error & 10 & 5,67 & 1,37 & 0,23 & 1,80 & 16,82 \\
C.V. $(\%)$ & & 4,87 & 2,37 & 1,3 & 3,21 & 9,5 \\
R $^{2}$ & & 0,93 & 0,97 & 0,95 & 0,79 & 0,77
\end{tabular}

DF, degrees of freedom; NHF, number of harvested fruits; FW, fruit weight; FL, fruit length; FD, fruit diameter *, significant; **, highly significant; ns, not significant

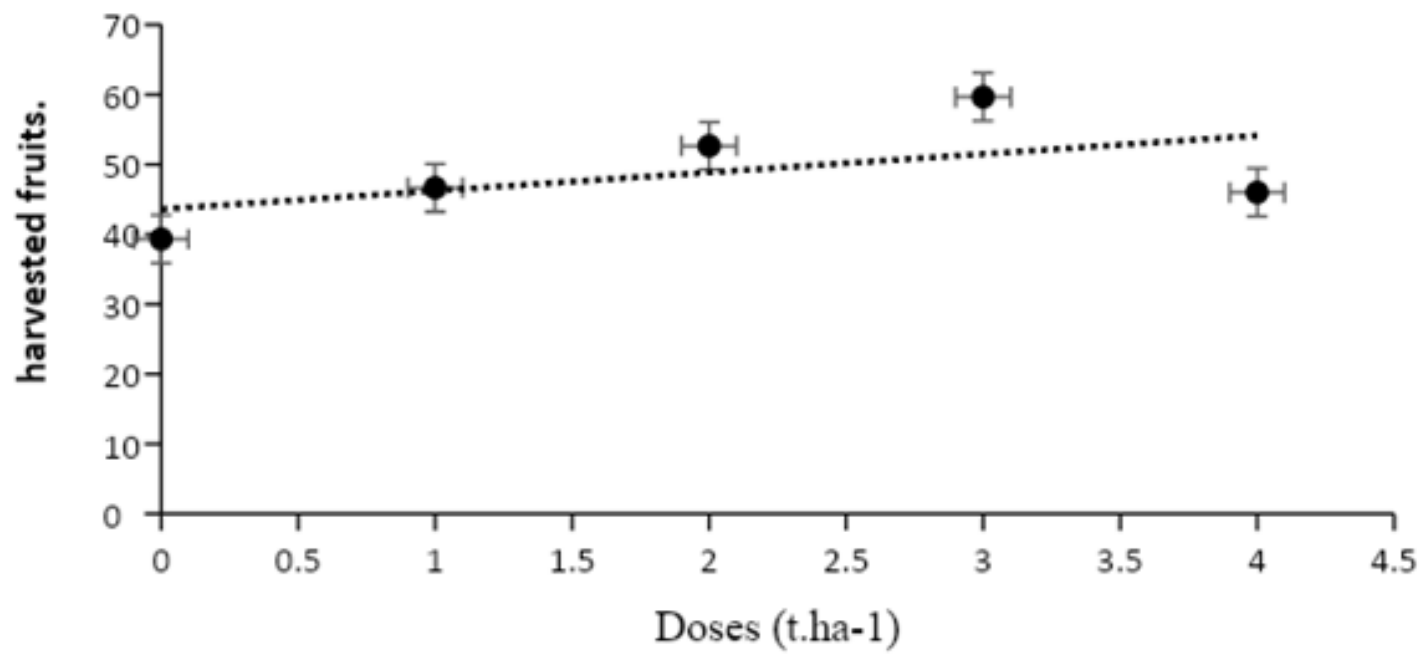

Figure 5 Effect of lime doses on the number of harvested fruits.

Fruit dimensions: According to Table 2, the dimensions of the fruit show significant variation between treatments. The modeling of the data conforms to a quadratic order model with statistical significance. The largest dimensions of the fruit are obtained with the dose of $2 \mathrm{t} \mathrm{ha}^{-1}$ (Figure 6), possibly with this dose the balance or sufficient amount of calcium in the soil was achieved to satisfy the needs of the tomato plant, which in turn it could positively influence the plant to absorb it together with other nutrients, in addition the calcium applied to the soil probably influenced the epidermal extensibility and the development of the tissues of the fruit's pericarp, this division and elongation of the tissues of the pericarp of the fruit, are determining for the growth of the tomato. ${ }^{29,30}$ In this regard, previous studies, ${ }^{31-}$ ${ }^{33}$ states that while epidermal cells divide throughout the development of the fruit, the division in the pericarp is limited to a short period of fruit development and it is located in the outer tissues around in the vascular bundles and in the hypodermis. Once the cell division ends, cell expansion begins to increase the size of the fruit. Likewise, it is possible that the increase in the diameter of the fruit is associated with the increase in the number and size of the cells as indicated by other researchers. ${ }^{34,47}$ The results of this research are similar to those reported by earlier studies, ${ }^{34-36,46}$ but differ from those reported by other researchers. ${ }^{12,37-39}$

Fruit weight: It can be evidenced that there is a highly significant variation between treatments (Table 3). As for the graphic behavior of the data, these fit a highly significant linear order model (Figure 7), this model indicates that there is a strong relationship between the two variables. This finding is possibly due to the fact that it is having an improved $\mathrm{pH}$ and more calcium available, it can be absorbed and incorporated into cell parts and influence the division of cells to induce fruit growth and weight. On the other hand, calcium that fails to enter the cytosol, remains in the cell wall, making them heavier. ${ }^{30}$ When calcium is properly supplied, it provides greater fruit establishment, greater growth and lower incidence of physiological disorders, together with an increasing number and weight of tomato fruits. ${ }^{35}$ These results are below $129 \mathrm{~g}$ reported by Muhammad et al., ${ }^{40}$ and $96.4 \mathrm{~g}$ reported by Martínez et al., ${ }^{41}$ but are consistent with those reported by other authors, ${ }^{34,35}$ who achieved increases in the weight of tomato fruit with calcium additions to the soil. However, Arruda et al., ${ }^{42}$ report contrary results, decrease in fruit weight. 


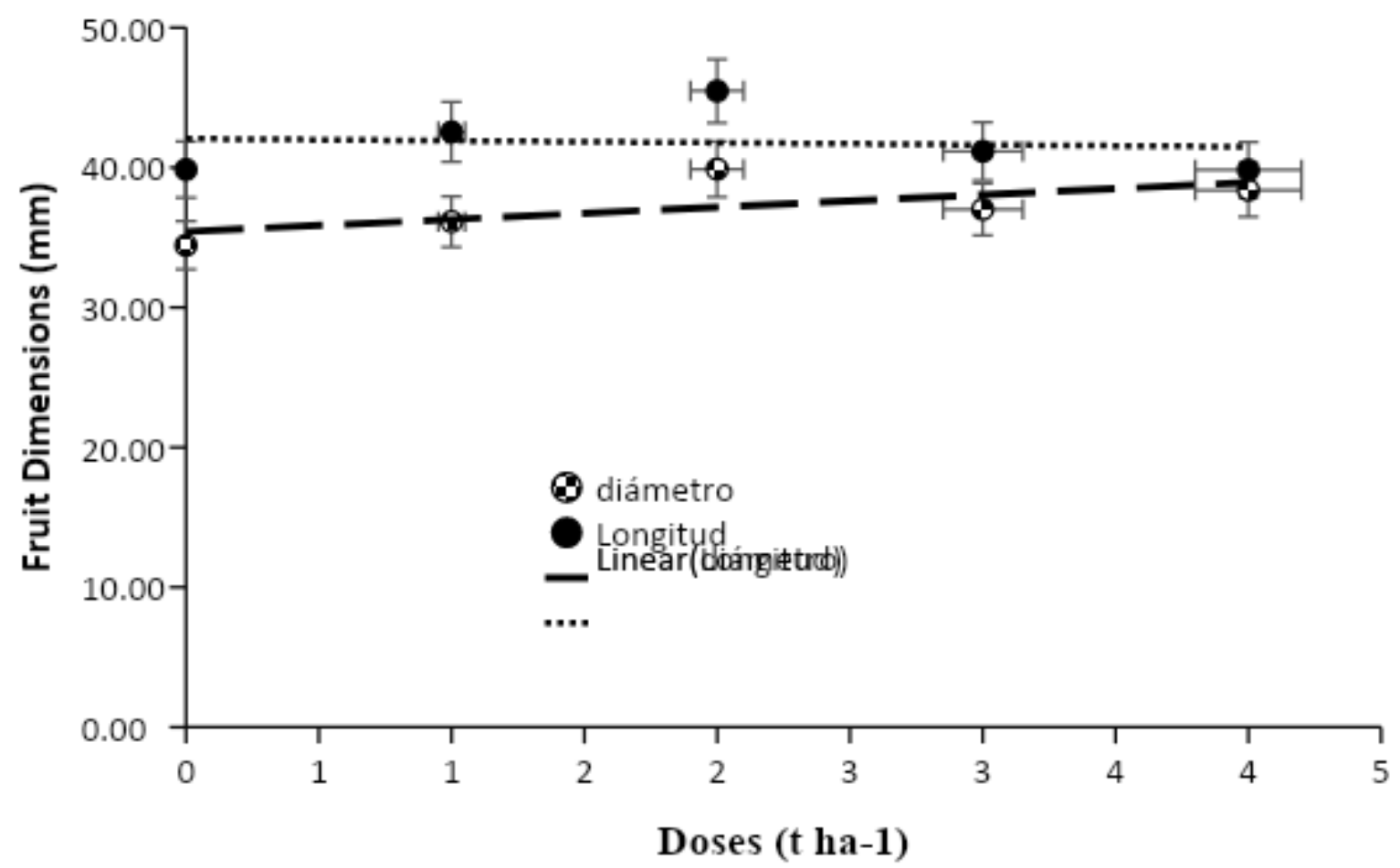

Figure 6 Effect of lime doses on tomato fruit dimensions in semi-controlled conditions.

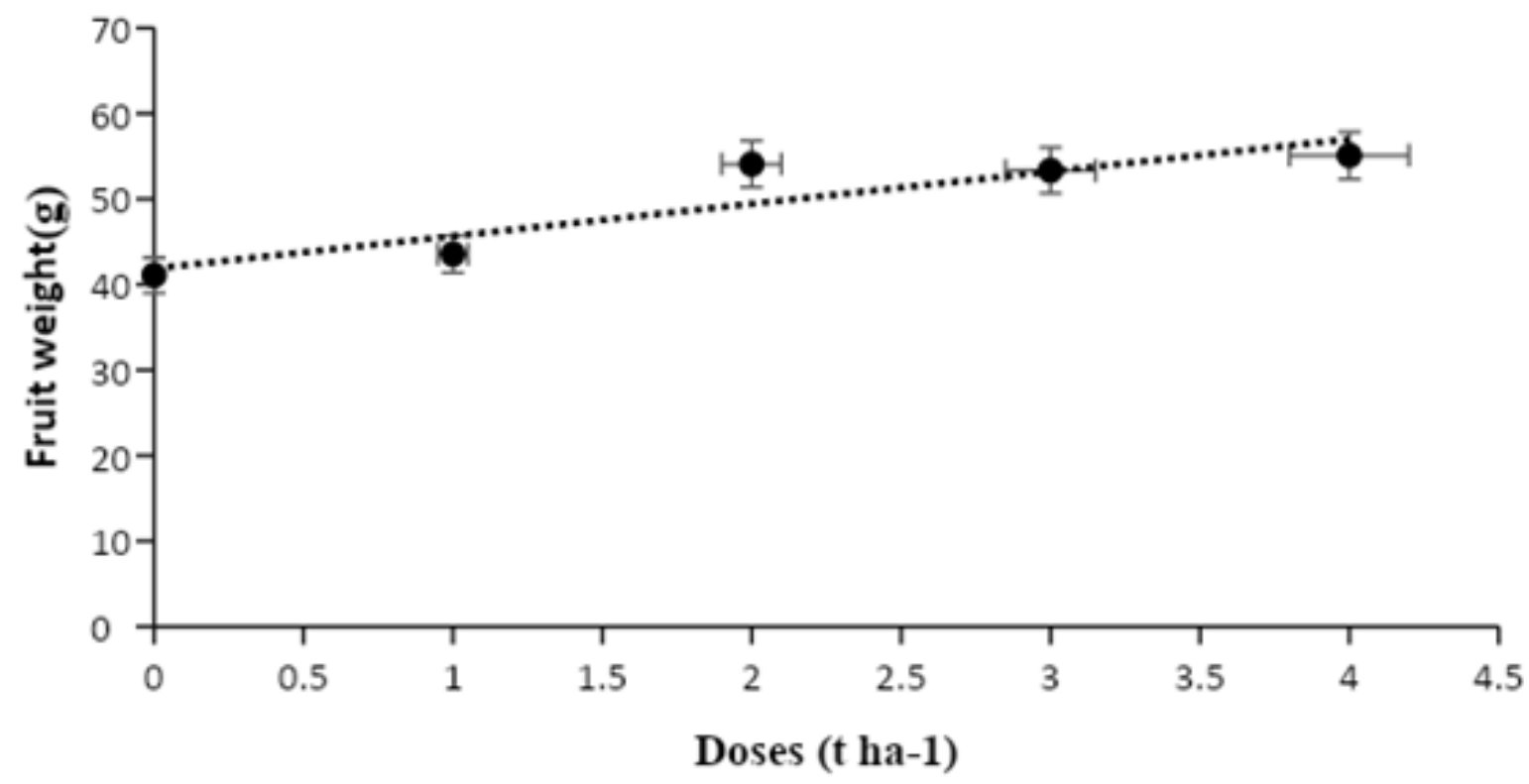

Figure 7 Effect of lime doses on tomato fruit weight.

Tomato yield: It is evident that the behavior of the data conforms to a quadratic order model (Figure 8) with statistical significance. The analysis of variance showed that there are significant differences between the treatments (Table 3$)$, the control treatment $\left(0 \mathrm{t} \mathrm{ha}^{-1}\right)$ is statistically similar to the treatments of 1,2 and $4 \mathrm{t} \mathrm{ha}^{-1}$ but different from the treatment of $3 \mathrm{t} \mathrm{ha}^{-1}$. It is evident that the treatments with lime showed higher values than the control, which suggests a strong tendency of the positive effect of calcium in this parameter evaluated.

The graph shows an increase in crop yield up to $3 \mathrm{t} \mathrm{ha}^{-1}$, from then on it tends to decrease, possibly because with larger doses the lime, the available calcium can negatively affect the chemically balanced soil, thereby decreasing the possibility of absorption of other nutrients. In this sense, Thompson ${ }^{43}$ states that calcium is essential for the division and cellular elongation of formed set fruits, favoring a larger size, however, it is required to take other nutrients proportionally.This increase in crop yield is possibly due to the fact that the availability of calcium in the soil improved the reaction of the soil and improved the chemical balance of the soil. When this occurs, the plants nourish much better and, therefore, will be more tolerant to the attack of pathogens. These results suggest that, with the liming practice and the fertilization plan based on the soil analysis, a good crop response is obtained in terms of production. These results are consistent with those reported by other researchers, ${ }^{10,35}$ but different from other authors. ${ }^{6,12,39,42,44,45-47}$ 


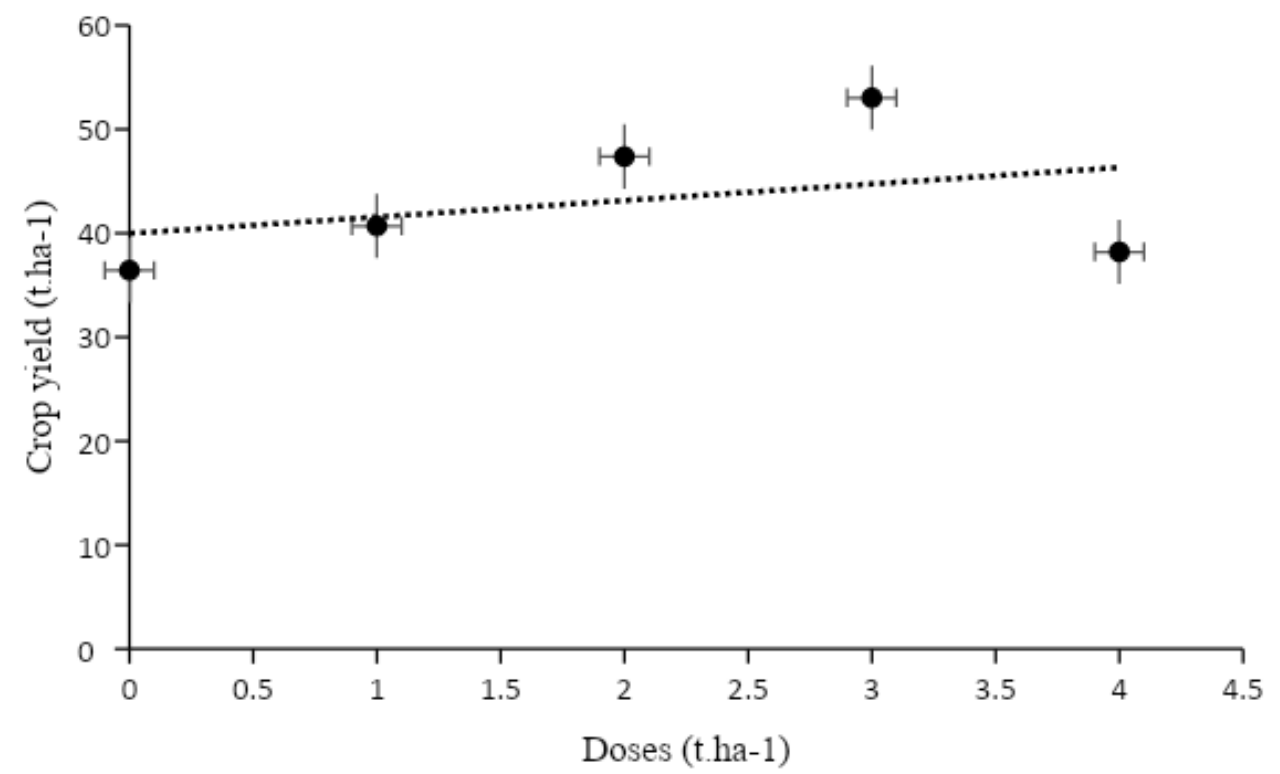

Figure 8 Effect of lime doses on tomato crop yield.

\section{Conclusion}

With the application of lime in acid soil of Sucre, better chemical conditions are achieved, the $\mathrm{pH}$ of the same is increased, which favors the nutritional availability, especially phosphorus and supply of interchangeable bases, which were used by the tomato crop.Liming and supply of nutrients in acidic soils with sandy characteristics and low nutritional offer can improve the production and characteristics (weight and dimensions) of tomato fruit, which is reflected in better yields of this crop.

\section{Acknowledgments}

The authors thank the administrative and technical support the Universidad de Córdoba, the University Corporation of the Caribbean (CECAR) and the Government of Sucre.

\section{Conflicts of interest}

This manuscript was prepared and reviewed with the participation of the authors, who declare that there is no conflict of interest that jeopardizes the validity of the results presented.

\section{Funding}

None.

\section{References}

1. Hue N. Alleviating Soil Acidity with crop residue. Soil Science. 2011;176(10):543-549.

2. Calva C, Espinosa J. Effect of the application of four liming materials in controlling the acidity of a soil from Loreto, Orellana. Sowing. 2017;4(1):110-120.

3. Rosas PG, Puentes PY, Menjivar FJ. Relationship between $\mathrm{pH}$ and nutrient availability for cocoa in an entisol from the Colombian Amazon. Corpoica Ciencia y Tecnología Agropecuaria. 2017;18(3):529-541.

4. Gómez M, Castro H, Pacheco W. Recover and management of actual acid sulphate soil in Boyacá (Colombia). Agr Col. 2005;23(1):128-135.
5. Đalović G, Jocković DS, Dugalić GJ, et al. Soil acidity and mobile aluminum status in pseudogley soils in Čačak-Kraljevo basin. Journal of the Serbian Chemical Society. 2012;7(6):833-843.

6. Cano S, Gallego M, Chavarriaga W. Effect of the application of calcium and phosphorus in an acidic soil and the response in the chonto tomato crop (Solanum lycopersicum (L.) Mill). Agron. 2011;19(1):77- 87.

7. Sadeghian KS. Soil fertility evaluation for adequate crop nutrition. Brown case. p.78. In: Book of summaries, XII Ecuadorian Congress of Soil Science. Santo Domingo, Ecuador; 2010.

8. Álvarez E, Viadé A, Fernández-Marcos ML. Effect of liming with different sized limestone on the forms of aluminium in a Galician soil (NW Spain). Geoderma. 2009;152(1-2):1-8.

9. Basak B, Biswak D. Potentiality of Indian rock phosphate as liming material in acid soil. Geoderma. 2016;263:104-109.

10. Faria CM, Costa ND, Faria AF. Lime and gypsum effects on soil chemical characteristics and on yield and quality of tomato and melon. Horticultura Brasileira. 2003;21(4):615-619.

11. Mayfield JL, Simonne EH, Mitchell CC, et al. Effect of liming materials on soil available nutrientes, yield, and grade distribution of doublecropped tomato and cucumber grown with plasticulture. Journal of Plant Nutrition. New York. 2001;24(1):87-99.

12. Cabrales E. Response to the application of Calcium on the apical rot of tomato fruit in the middle Sinú Valley (Córdoba, Colombia). Equatorial soils. 2010;40(1):68-72.

13. Cochrane TT, Salinas JG, Sánchez PA. An equation for liming acid mineral soils to compesate crops aluminium tolerance. Revista Tropical Agriculture. 1980;57(2):133-140.

14. Pan XY, Li JY, Deng KY, et al. Four-year effects of soil acidity amelioration on the yields of canola seeds and sweet potato and $\mathrm{N}$ fertilizer efficiency in an ultisol. Field Crops Research. 2019;237:1-11.

15. Xu D, Carswell A, Zhu Q, et al. Modelling long-term impacts of fertilization and liming on soil acidification at Rothamsted experimental station. Science of The Total Environment. 2020;136249.

16. Bennardi D, Díaz A, Juan L, et al. Evaluation of the buffer capacity of acid soils in the Pampean region. Science. Soil (Argentina). 2018;36(1):30-38 
17. Guckland A, Ahrends B, Paar U, et al. Predicting depth translocation of base cations after forest liming: results from long-term experiments. European Journal of Forest Research. 2012;131(6):1869-1887.

18. Cravo M, Smyth J, Carvalho E. Liming in a dystrophic yellow latosol from the Amazon and its influence on chemical attributes of the soil and on the productivity of annual crops. Brazilian Journal of Soil Science. 2012;36:895-907.

19. Ameliorating Soil Acidity of Tropical Oxisols by Liming for sustainable crop production. In: D Sparks, editor. Advances in Agronomy. London: Elsevier. 2008;99:345-399.

20. De Mello Prado R, Natalle W. Liming on calcium nutrition and on the development of the guava root system. Pesquisa Agropecuária Brasileira. 2004;39(10):1007-1012.

21. Anikwe MA, Eze JC, Ibudialo AN. Influence of lime and gypsum application on soil properties and yield of cassava (Manihot esculenta Crantz.) in a degraded Ultisol in Agbani Enugu Southeastern Nigeria. Soil and Tillage Research. 2016;158:32-38.

22. Sikiric B, Cakmak D, Saljnikov E, Optimization of macroelement contents in raspberry leaves by liming in an extremely acid soil. Spanish Journal of Agricultural Research. 2011;9(1):329-337.

23. T Chatzistathis, D Alifragis, A Papaioannou. The influence of liming on soil chemical properties and on the alleviation of manganese and copper toxicity in Juglans regia, Robinia pseudoacacia, Eucalyptus sp. and Populus sp. plantations. Journal of Environmental Management. 2015;150:149-156.

24. Castro H, Munevar O. Chemical improvement of acidic soils through the combined use of liming materials. Rev UDCA Act. \& Div. Cient. 2013;16(2):409-416.

25. Saure MC. Why calcium deficiency is not the cause of blossom-end rot in tomato and pepper fruit - a reappraisal. Scientia Horticulturae. 2014;74:151-154.

26. Dhall RK, Singh P. Effect of ethephon and ethylene gas on ripening and quality of tomato (Solanum Lycopersicum L.) during cold storage. Journal of Nutrition \& Food Sciences. 2013;3(6):244.

27. Kiferle C, Gonzali S, Holwerda TH, et al. Tomato fruits: a good target for iodine biofortification. Frontier in Plant Science. 2013;4:205.

28. Landini M, Gonzali S, Perata P. Iodine biofortification in tomato. Journal of Plant Nutrition and Soil Science. 2011;174(3):480-486.

29. Aroca DR, Pérez AJ, Callejón FA, et al. Morphology, yield and quality of greenhouse tomato cultivation with flexible photovoltaic rooftop panels (Almería-Spain). Scientia Horticulturae. 2019;257:108768.

30. Rongaa D, Franciaa E, Rizzab F, et al. Changes in yield components, morphological, physiological and fruit quality traits in processing tomato cultivated in Italy since the 1930's. Scientia Horticulturae. 2019;257:108726.

31. Salcedo MF, Colman SL, Mansilla AY, et al. Amelioration of tomato plants cultivated in organic-matter impoverished soil by supplementation with Undaria pinnatifida. Algal Research. 2020;46:101785.

32. Zhanga L, Wanga $P$, Suna $X$, et al. Calcium permeation property and firmness change of cherry tomatoes under ultrasound combined with calcium lactate treatment. Ultrasonics - Sonochemistry. 2019;60:104784.
33. Nyalalaa I, Okindaa C, Nyalalab L, et al. Tomato volume and mass estimation using computer vision and machine learning algorithms: Cherry tomato model. Journal of Food Engineering. 2019;263:288-298.

34. Martinez-Damián MT, Cano-Hernández R, Moreno-Pérez EC, et al. Effect of preharvest growth bioregulators on physicochemical quality of saladette tomato. Revista Chapingo Serie Horticultura. 2019;25(1):2943.

35. Zamban DT, Prochnow D, Caron BO, et al. Calcium and boron applications increase the production of Italian tomato hybrids (Solanum lycopersicum) in two growing seasons. Colombian Journal of Horticultural Sciences. 2018;12(1):82-93.

36. Silva MW, CJ Jadoski, EO Ono, et al. Calcium, boron and plant regulators in fruit fixation in tomato. Search Applied Agrotecnol. 2009;2(3):103112.

37. Afsana N, Mahbub M, Hossain E, et al. Response of Tomato (Solanum lycopersicum L.) to Salicylic Acid and Calcium. Journal of Applied Life Sciences International. 2017;15(2):1-7.

38. Abbasi N, Zafar L, Khan H, et al. Effects of naphthalene acetic acid and calcium chloride application on nutrient uptake, growth, yield and postharvest performance of tomato fruit. PakJ Bot. 2013;45(5):1581-1587.

39. Rab A, Haq I. Foliar application of calcium chloride and borax influences plant growth, yield, and quality of tomato (Lycopersicon esculentum Mill.) fruit. Turk J Agric. 2012;36:695-701.

40. Muhammad A, Wong C, Mahamud S. The efficacy of calcium formulation for treatment of tomato blossom-end rot. J Trop Agric and Fd Sc. 2012;40(1): 89-98.

41. Martínez L, Velasco V, Ruiz J, et al. Effect of calcium nitrate and substrates on tomato yield. Mexican Journal of Agricultural Science. 2013;6:1175-1184

42. Arruda Júnior SJ, Bezerra Neto E, Barreto LP, et al. Apical rot and productivity of the tomato through the contents of calcium and ammonium. Revista Caatinga. 2011;24(4):20-26.

43. Thompson DS. Extensiometric determination of the rheological properties of the epidermis of growing tomato fruit. Journal of Experimental Botany. 2001;52:1291-1301.

44. Machado AQ, Alvarenga MA, Florentino CE. Production of Italian tomatoes (saladete) under different planting densities and pruning systems for fresh consumption. Hortic Bras. 2007;25:149-153.

45. Olego MA, Visconti F, Quiroga MJ, et al. Assessing the effects of soil liming with dolomitic limestone and sugar foam on soil acidity, leaf nutrient contents, grape yield and must quality in a Mediterranean vineyard. Spanish Journal of Agricultural Research. 2016;14(2):e1102.

46. Oliveira PS, de Oliveira AS, Silva GM, et al. Calcium carbonate particle films and water regimes affect the acclimatization, ecophysiology and reproduction of tomato. Environmental and Experimental Botany. 2019;165:19-29.

47. Shinozaki Y, Hao S, Kojima M, et al. Ethylene suppresses tomato (Solanum lycopersicum) fruit set through modification of gibberellin metabolism. The Plant Journal. 2015;83(2):237-251. 